\title{
Research Article: Credibility of information sources utilised by tomato growers in Nashik district of Maharashtra state
}

\section{PARMESHWARI B. PAWAR, S.M. HADOLE AND T.B. UGALE}

Article Chronicle: Received :

17.07.2017;

Revised :

29.08.2017;

Accepted :

15.09.2017

KEY WoRds:

Credibility, Source, Information, Tomato growers

Author for correspondence : PARMESHWARI B.

PAWAR

Department of

Extension Education,

K.K. Wagh College of

Agriculture,

Saraswatinagar,

Panchavati, NASHIK

(M.S.) INDIA

Email:pari2805@

rediffmail.com

See end of the article for

authors' affiliations
SUMMARY : Credibility refers to the trustworthiness of information sources as perceived by farmers is an important factor. The present study was conducted in two blocks of Nashik district of Maharashtra state to investigate the credibility of differnt information sources utilize by tomato growers. The present study revealed that the agri. input retailers perceived as most credible followed by social media/ internet, agricultural consultant and agri. input company representative. On the other hand village level worker, co-operative society and government extension agencies were perceived as least credible sources.

How to cite this article : Pawar, Parmeshwari B.,Hadole, S.M. and Ugale, T.G. (2017). Credibility of information sources utilised by tomato growers in Nashik district of Maharashtra state. Agric. Update, 12(4): 569-573; DOI : 10.15740/HAS/AU/12.4/569-573. 